\title{
Pain and Anxiety in Cataract Surgery: Comparison Between the First and Second Eye Surgeries
}

\section{Katarakt Cerrahisinde Ağrı ve Anksiyete: Birinci Göz ve İkinci Göz Cerrahisi Arasında Karşılaştırma}

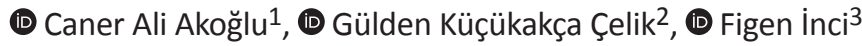 \\ ${ }^{1}$ Erciyes University Faculty of Medicine, Department of Neurosurgery, Kayseri, Turkey \\ ${ }^{2}$ Nevşehir Hacı Bektaş Veli University Semra-Vefa Kucuk Faculty of Health Sciences, Department of Nursing, Nevşehir, Turkey \\ ${ }^{3}$ Niğde Ömer Halis Demir University, Zübeyde Hanım School of Health, Department of Nursing, Niğde, Turkey
}

Keywords

Topical anesthesia, bilateral cataract surgery, perioperative process, pain, anxiety

\section{Anahtar Kelimeler}

Topikal anestezi, bilateral katarakt cerrahisi, perioperatif süreç, ağrı, anksiyete

Received/Geliş Tarihi : 06.07.2020

Accepted/Kabul Tarihi : 07.03.2021

doi:10.4274/meandros.galenos.2021.28199

Address for Correspondence/Yazışma Adresi: Gülden Küçükakça Çelik Ph.D., Nevşehir Hacı Bektaş Veli University SemraVefa Kucuk Faculty of Health Sciences, Department of Nursing, Nevșehir, Turkey Phone : +90 5073529235

E-mail : guldenkucukakca@nevsehir.edu.tr ORCID ID: orcid.org/0000-0002-8325-3198

(C) Meandros Medical and Dental Journal, Published by Galenos Publishing House.

This is article distributed under the terms of the Creative Commons Attribution NonCommercial 4.0 International Licence (CC BY-NC 4.0).

\begin{abstract}
Objective: This study aimed to determine and compare the pain and anxiety levels in the perioperative period of patients undergoing cataract surgery on both eyes. Materials and Methods: The study used a descriptive design to assess 60 patients who had undergone cataract surgery on both eyes. The visual analog scale (VAS) and the State-Trait Anxiety Inventory were used to evaluate the subjective parameters of patients in the surgical process. Objective measurements in the perioperative process were recorded in the physiological parameters form.

Results: The state anxiety levels of patients in the preoperative period of the first eye surgery were found to be higher compared with that of the second eye surgery $(p=0.003)$. In addition, patients were determined to have more severe anxiety in the preoperative period of the first eye surgery (VAS: 4.510) and before (VAS: 4.483) and during the perioperative period (VAS: 4.150) of the second eye surgery. Patients had a higher pain score and a higher state of anxiety after clinic admission in the postoperative period of the second eye surgery compared with that of the first eye surgery $(p<0.05)$. The diastolic blood pressure value before the operation and the pulse and respiratory rate during the operation were higher in the first eye surgery than in the second eye surgery $(p=0.038 ; p=0.000 ; p=0.000$, respectively).

Conclusion: The results of the subjective and objective measurements revealed that the anxiety experienced in the first cataract surgery made the perceived anxiety and sensation of pain more sensitive in the second eye surgery.
\end{abstract}

Öz

Amaç: Bu çalışma her iki gözde katarakt ameliyatı geçiren hastaların perioperatif dönemdeki ağrı ve anksiyete düzeylerini belirlemek ve karşılaştırmak amacıyla yapıldı.

Gereç ve Yöntemler: Tanımlayııı nitelikte olan çalışmanın örneklemini, her iki göze katarakt cerrahisi uygulanan 60 hasta oluşturdu. Vizuel analog skala (VAS) ve Durumluk Sürekli Kaygı Envanteri, hastaların cerrahi süreçteki subjektif parametrelerini değerlendirmek için kullanıldı. Perioperatif süreçte değerlendirilen objektif ölçümler ise fizyolojik parametre formuna kaydedildi.

Bulgular: Ameliyat öncesi dönemde hastaların durumluk kaygı düzeyleri ikinci göz cerrahisine göre daha yüksek bulundu $(p=0,003)$. Ayrıca hastaların ilk göz cerrahisi 
ameliyat öncesi dönemde (VAS: 4,510) ve ikinci göz cerrahisi ameliyat öncesi (VAS: 4,483) ve ameliyat esnasında (VAS: 4,150) daha şiddetli anksiyeteye sahip oldukları belirlendi. İkinci göz cerrahisi ameliyat sonrası dönemde, hastaların ilk göz cerrahisine göre ağrı düzeyleri ve kliniğe alındıktan sonra durumluk anksiyete düzeyleri daha yüksekti $(p<0,05)$. Illk göz cerrahisinde ameliyat öncesi ölçülen diyastolik kan basıncı değeri ve ameliyat sırasında ölçülen nabız ve solunum hızı ikinci göz cerrahisinde ölçülen değerlerden daha yüksekti (sırasıyla $p=0,038 ; p=0,000 ; p=0,000$ ).

Sonuç: Bu çalışmada; subjektif ve objektif ölçümlerin sonuçları, ilk katarakt cerrahisinde yaşanan kaygının, ikinci göz cerrahisinde algılanan kaygı ve ağrı hissini daha duyarlı hale getirdiğini ortaya koymuştur.

\section{Introduction}

Cataract surgery is the most frequently performed surgery in the world, and with the developing technology today, the operation time is quite short. The surgical procedure is often performed under local anesthesia $(1,2)$. During the surgical procedure, topical anesthesia is preferred to ensure the comfort of the surgeon and to speed up the recovery time of the patient (3).

Topical anesthesia is a method that can be applied fast in cataract surgery, and it is known to reduce the risk of complications in the patient (4). However, studies report that, besides this positive feature of topical anesthesia, it causes pain ranging between $34 \%$ and $90 \%$ both during and after surgery (4-6). Patients are awake so that they can follow the surgeon's directives during the operation and this may cause anxiety (7), and also lead to negative consequences in physiological parameters such as hypertension or tachycardia (8).

Since the prospect of feeling pain and loss of visual function is a fearful condition, patients may be highly anxious before surgery (9). Patients can move due to anxiety and pain during the operation and lose their visual function due to complications such as hemorrhage or postoperative glaucoma. Therefore, evaluating and controlling pain and anxiety during the operation is important in terms of ensuring patient comfort and prognosis of the surgery (10). In cataract surgery, the management of pain and anxiety does not only reduce the anxiety of patients but also increases patient collaboration during surgery (8).

Studies in the literature report that, in the evaluation of subjective symptoms of patients with bilateral cataracts, there are differences between the first and second eye surgery (8,11-15). Pain, which is among these symptoms in cataract surgery, has been studied quite widely $(1,3,6,8,11-18)$. However, there are fewer studies on cataract surgery where pain and anxiety are evaluated together $(8,12,15,19)$.

In studies comparing pain and anxiety between the two eye surgeries $(8,12,15,19)$, anxiety was evaluated before the surgery and pain during or after surgery. In a study evaluating pain and anxiety in patients undergoing cataract surgery in both eyes, the results of pain and anxiety between the first and second eye surgery of different patients were compared (8). In the study of Yu et al. (15), objective measurements such as physiological parameters were not included in the data. In these studies in the literature of the last decade $(8,12,15,19)$, pain and anxiety level assessment included different phases of cataract surgery.

When the study results were examined, anxiety levels of the patients were determined to be lower before the second eye surgery, whereas the severity of the pain was higher during the surgery $(8,12,15)$. While some researchers examining the increased pain during the second eye surgery stated that anxiety was the underlying cause of the increased pain in the second eye surgery (20), there are also different study results suggesting that it depended on patient's perception $(14,21)$.

Due to differences in previous study methods, measurement times, and findings, it is necessary to carry out studies to strengthen the level of evidence by evaluating the pain and anxiety of patients undergoing cataract surgery in the perioperative process. According to the review of the literature, no studies evaluating the pain and anxiety together in patients undergoing cataract surgery on both eyes during the entire surgical process were found. Therefore, the present study is considered to be original.

This study was carried out to determine and compare the pain and anxiety levels in the perioperative period of patients undergoing cataract surgery on both eyes. 


\section{Materials and Methods}

\section{Setting}

The study was carried out in the ophthalmology and surgery clinic and operating room of a state hospital between October 2018 and July 2019. Operations for ophthalmology are conducted according to daily surgery procedures, and the eye surgery process is managed with 5 specialist doctors in 5 polyclinics.

\section{Sample}

The universe of the study consisted of 128 patients who underwent bilateral phacoemulsification surgery due to cataract and who presented to the ophthalmology surgery outpatient clinic. The following patients were excluded from the study: 4 patients who were administered a preliminary application, 9 patients who had had surgery due to non-cataract eye disease previously, 17 patients who gave up the second eye surgery, 28 patients who were reluctant to collaborate, 4 patients who preferred a different doctor for the second eye surgery, 1 patient who developed complications during surgery, and 5 patients who were not eligible for topical anesthesia. Accordingly, the study was completed with 60 patients. The sample size of the study was calculated on the $\mathrm{G}^{*}$ Power 3.1.9.2 software package by accepting a 1 unit increase in visual analogue scale (VAS) pain severity between the first eye and the second eye surgery as significant (8). As a result of post-hoc power analysis, the study was determined to have $99 \%$ power with $1 \%$ type 1 error.

\section{Inclusion and Exclusion Criteria}

The inclusion criteria included patients who were aged over 18, who could communicate verbally, who underwent bilateral phacoemulsification surgery, whose both eye operations were carried out by the same surgeon, who were administered a surgical procedure under topical anesthesia, and who did not have any non-cataract eye diseases such as ocular surgery, glaucoma, uveitis, and keratoconus, and a psychiatric diagnosis.

On the other hand, the exclusion criteria included patients who were not eligible for collaboration, whose second eye surgery was performed by a different surgeon, who refused to have second eye surgery, who developed postoperative complications, and for whom topical anesthesia was not adequate during surgery and different intraocular anesthesia was preferred.

\section{Measurements}

A patient information form, which was made up of two sections, was used to collect information about the patients. The first section of the form included a total of 15 questions to determine the socio-demographic characteristics of the participants such as age, gender, educational status, income level, and place of residence, and the properties of surgical procedures such as the duration of surgery in the operating theater and the duration between the two operations. On the other hand, the second section of the form consisted of two questions evaluating the difference between the pain and anxiety levels experienced by patients in both eye operations.

To determine the State-Trait Anxiety InventoryState (STAI-S) and STAI-Trait (STAI-T) anxiety levels of the patients, a 4-point Likert-type Spielberg State-Trait Anxiety scale consisting of two parts, each of which contained 20 questions, was used. The scale was developed by Spielberger et al. (22). It was adapted to Turkish society by Öner and Le Compte (23). Each item on the scale is responded using one of the four options including "not at all", "somewhat", "much", and "fully" to determine the intensity of behavior and emotions. The total score obtained from the scale consisting of two parts varies between 20 and 80 . High scores indicate a high level of anxiety and low scores indicate a low level of anxiety. In this study, Cronbach's $\alpha$ was found to be 0.83 for STAI-S and 0.85 for STAI-T.

To evaluate patients' pain and anxiety levels, we used the VAS, a $10 \mathrm{~cm}$-long horizontal line, which was developed by Cline et al. (24) and adapted to Turkish by Eti-Aslan (25). For the anxiety, the left side of the scale reads "no anxiety" and the right side reads "extreme anxiety". On the VAS pain scale, on the other hand, one end of the line reads "no pain" and the other end reads "unbearable pain". Values range from 0 to 10 , and high values indicate increased anxiety and pain.

Also, a form for physiological parameters, which was developed by the researcher, was used to collect data about objective measurements of patients including systolic and diastolic blood pressure value, pulse and respiratory rate, and oxygen saturation value. 


\section{The Procedure}

The data were collected by the researcher. At the outset, the forms were piloted to 4 patients to assess the applicability of the forms. These patients were not included in the sample group.

The purpose of the study was explained to the patients who presented to the ophthalmology and surgery outpatient clinic for cataract, who were planned to undergo phacoemulsification surgery on both eyes, and who met the study criteria. The contact information and written consent of the patients were obtained.

Data on pain, anxiety, and physiological parameters were collected in a five-stage process in both eye surgeries. The first stage started with the hospitalization of the patient. Patients who came to the clinic were assessed for anxiety levels with STAI-S and STAI-T, the severity of anxiety with VAS, and physiological parameters. To achieve the full dilation of the pupils, the eye was administered medication by nurses at the clinic 30 minutes before the surgery. The patients were delivered to the operating room nurses by the clinical nurses for the surgical intervention, and the second phase of the data collection process was initiated. In the second stage, the anxiety and physiological parameters of the patients were assessed with VAS just before the operation. Then, patients were taken to the operating room for phacoemulsification surgery and monitored.

Phacoemulsification is known as closed system cataract surgery, which allows the lens material to be broken up and removed by ultrasound. It has superior advantages compared to other cataract surgeries in terms of short operation time, small incision area, less astigmatism, less inflammation and rapid recovery after the operation (26).

The operating theatre and all procedures performed using surgical equipment and instruments were used in all patients and both eye surgeries without making any change. The conjunctival area was washed with povidone-iodine $(0.02 \%) 5$ minutes before surgery. With the administration of $5 \%$ proparacaine, topical anesthesia application involved 3 stages, including 5 minutes before the operation, 1 minute before the operation, and after placing the retractor. The patients were not administered oral and intravenous sedative or analgesic medication. All procedures were applied to the patients by the same surgeon in both eye surgeries.

The VAS scale used in the third stage to determine the pain and anxiety of the patients during surgery was evaluated after the phacoemulsification process was completed after the corneal incision and the lens was placed and the viscoelastic aspiration of the intraocular residues was done. At the same time, physiological parameters were followed on the monitor and recorded on the related form. Immediately after the operation was completed, the patient was taken to the follow-up room, and then the fourth stage process involving pain, anxiety, and physiological parameter evaluations was performed.

The fifth stage started approximately one hour later when the patient was taken to the clinical room. At this stage, the STAI-S, VAS and physiological parameters evaluation form was re-administered to the patients. After the completion of both eye surgeries, patients were asked to evaluate the difference between pain and anxiety they experienced in both eye surgeries with the following possible answers: "I had more pain in the first eye surgery"; "I had more anxiety in the first eye surgery"; "I had more pain in the second eye surgery"; "I had more anxiety in the second eye surgery"; "I had the same anxiety in both eye surgeries"; "I had the same pain in both eye surgeries". The responses given by the patients were recorded in the second part of the patient information form, and the evaluation steps for pain and anxiety were completed.

Collection in of $1^{\text {st }}$ and $2^{\text {nd }}$ eye surgery data was conducted between 08:00 and 16:00, according to the time when the patients were taken to the surgery. For each eye surgery, the data collection process consisting of the stages such as obtaining written permission from the patient, administration of the preoperative, perioperative, and postoperative measurement tools took approximately 60 minutes. Approximately 120 minutes was allocated for data collection in both eye surgeries for each patient.

\section{Statistical Analysis}

Data were analyzed using the Statistical IBM SPSS Statistics 22 (IBM SPSS; Turkey). The suitability of the variables to normal distribution was evaluated by the Shapiro-Wilks test. Categorical measurements were calculated as numbers and percentages, while 
numerical measurements were calculated as mean, standard deviation, and frequency values. The paired sample t-test was employed to compare the results of the first and the second surgical interventions, the repeated measures ANOVA was used to evaluate the measurements obtained during interventions, and Bonferroni test was used to determine which measurement caused the difference in the group. In all statistical analyses, significance level was accepted as $\mathrm{p}<0.05$.

\section{Ethical Considerations}

At the outset, the Ethics Committee approval (decision no: 2018/10, date: 10.09.2018) of Nevşehir Hacı Bektaş Veli University, institutional permission of the state hospital where the data were collected (issue 55831188-604.02), and the written consent of the participants were obtained. The data were collected and securely stored by the researchers as required.

\section{Results}

\section{Patient Characteristics}

The mean age of the patients was $65.65 \pm 6.51$ years, $60.0 \%$ were female, $70.0 \%$ were literate or primary school graduates, $93.3 \%$ were married, and $55.0 \%$ were housewives. Also, $70 \%$ of the patients were determined to perceive their income and expenses as equal, $36.7 \%$ lived in a village/town, and $50.0 \%$ lived with their spouses. Besides, $66.7 \%$ of the patients had a chronic disease, and $80.0 \%$ had undergone an operation before (Table 1 ). The duration of patients' cataract complaints was $20.22 \pm 34.67$ months, and the mean time between the two surgeries was $28.77 \pm 26.45$ days. There was no statistically significant difference between the operating-room duration of the patients' $1^{\text {st }}$ and $2^{\text {nd }}$ surgeries ( $p>0.05$ ) (Table 2 ).

\section{Comparison of Subjective Anxiety}

The within-group and between-group comparisons of the severity of anxiety levels were made (Table 3 ). When the means of STAI-T and VAS-anxiety scores were compared between the groups, there was no statistically significant difference between the $1^{\text {st }}$ and $2^{\text {nd }}$ eye surgeries $(p>0.05)$. In the $2^{\text {nd }}$ eye surgery, the STAI-S anxiety score measured before going to the operating room was found to be lower than the $1^{\text {st }}$ eye surgery $(p<0.05)$. When comparing the within-group mean scores of STAI-S anxiety, the anxiety scores

\begin{tabular}{|c|c|c|c|}
\hline & $\overline{\mathbf{x}}$ & SD & \\
\hline \multirow[t]{2}{*}{ Age (49-82) } & 65.65 & 6.51 & \\
\hline & & $\mathbf{n}$ & $\%$ \\
\hline \multirow{2}{*}{ Gender } & Female & 36 & 60.0 \\
\hline & Male & 24 & 40.0 \\
\hline \multirow{5}{*}{ Education } & Illiterate & 7 & 11.7 \\
\hline & $\begin{array}{l}\text { Literate or primary } \\
\text { school }\end{array}$ & 42 & 70.0 \\
\hline & Secondary school & 4 & 6.7 \\
\hline & High school & 5 & 8.3 \\
\hline & $\begin{array}{l}\text { University and higher } \\
\text { education }\end{array}$ & 2 & 3.3 \\
\hline \multirow{2}{*}{ Marital status } & Married & 56 & 93.3 \\
\hline & Single & 4 & 6.7 \\
\hline \multirow{4}{*}{ Occupation } & Retired & 25 & 41.7 \\
\hline & Housewife & 33 & 55.0 \\
\hline & Worker & 1 & 1.7 \\
\hline & Other & 1 & 1.7 \\
\hline \multirow{3}{*}{ Income status } & $\begin{array}{l}\text { Income less than } \\
\text { expenses }\end{array}$ & 17 & 28.3 \\
\hline & $\begin{array}{l}\text { Income equal to } \\
\text { expenses }\end{array}$ & 42 & 70.0 \\
\hline & $\begin{array}{l}\text { Incomes more than } \\
\text { expenses }\end{array}$ & 1 & 1.7 \\
\hline \multirow{3}{*}{ Place of residence } & City & 21 & 35.0 \\
\hline & District & 17 & 28.3 \\
\hline & Village/town & 22 & 36.7 \\
\hline \multirow{4}{*}{$\begin{array}{l}\text { People living } \\
\text { together at home }\end{array}$} & Alone & 5 & 8.3 \\
\hline & With spouse & 30 & 50.0 \\
\hline & With children & 6 & 10.0 \\
\hline & $\begin{array}{l}\text { With spouse and } \\
\text { children }\end{array}$ & 19 & 31.7 \\
\hline \multirow{2}{*}{$\begin{array}{l}\text { Presence of chronic } \\
\text { disease }\end{array}$} & Yes & 40 & 66.7 \\
\hline & No & 20 & 33.3 \\
\hline \multirow{5}{*}{$\begin{array}{l}\text { *Type of chronic } \\
\text { disease }\end{array}$} & HT & 28 & 70 \\
\hline & DM & 18 & 45 \\
\hline & COPD & 8 & 20 \\
\hline & $\mathrm{HF}$ & 10 & 25 \\
\hline & $* *$ Other & 3 & 7.5 \\
\hline \multicolumn{4}{|c|}{$\begin{array}{l}\text { *Multiple answer options are marked, }{ }^{* *} \text { Ulcerative colitis, celiac, } \\
\text { breast cancer. HT: Hypertension, DM: Diabetes mellitus, COPD: Chronic } \\
\text { obstructive pulmonary disease, HF: Heart failure }\end{array}$} \\
\hline
\end{tabular}


measured in the clinic after the operation in the $2^{\text {nd }}$ eye surgery were higher than the mean scores measured before going to the operating theater $(p<0.05)$. In the within-group evaluation of VAS anxiety mean scores, the difference between the $1^{\text {st }}$ and $2^{\text {nd }}$ eye surgery within-group anxiety mean scores was found to be statistically significant $(p<0.05)$. In further analyses conducted to determine which measurement caused this difference, it was determined to stem from the high anxiety scores measured before the operation in

\begin{tabular}{|c|c|c|c|}
\hline & & $\mathbf{n}$ & $\%$ \\
\hline \multirow{3}{*}{$\begin{array}{l}\text { Status of undergoing an } \\
\text { operation before }\end{array}$} & Yes & 48 & 80.0 \\
\hline & No & 12 & 20.0 \\
\hline & $\overline{\mathbf{x}}$ & \multicolumn{2}{|l|}{ SD } \\
\hline $\begin{array}{l}\text { Duration of cataract } \\
\text { complaint (moon) }\end{array}$ & 20.22 & \multicolumn{2}{|c|}{34.67} \\
\hline $\begin{array}{l}\text { Period between two } \\
\text { cataract surgeries (day) }\end{array}$ & 28.77 & \multicolumn{2}{|c|}{26.45} \\
\hline \multicolumn{4}{|c|}{ Time spent in operating room (minute) } \\
\hline First surgery & 21.97 & \multicolumn{2}{|c|}{10.72} \\
\hline Second surgery & 21.32 & \multicolumn{2}{|l|}{7.06} \\
\hline \multicolumn{4}{|l|}{ SD: Standard deviation } \\
\hline
\end{tabular}

the $1^{\text {st }}$ eye surgery and those measured before and during the operation in the $2^{\text {nd }}$ eye surgery (Table 3 ).

\section{Comparison of Perceived Subjective Pain}

The within-group and between-group comparisons of the severity of pain levels were conducted (Table 4). In the between-group evaluation of patients' VAS pain severity, the pain score measured after the operation was higher in the $2^{\text {nd }}$ eye surgery compared to the $1^{\text {st }}$ eye surgery $(p<0.05)$. In the within-group evaluation, in the $2^{\text {nd }}$ eye surgery, the within-group difference between the mean scores of pain was found statistically significant $(p<0.05)$. In further analyses to determine which measurement caused this difference, it was determined to come from the high pain scores measured soon after the surgery (Table 4).

\section{Comparison of Objective Measures}

The within-group and between-group comparisons regarding the physiological parameters of the patients were conducted (Table 5). In the withingroup and between-group comparisons, there was no statistically significant difference between systolic blood pressure and oxygen saturation values in the $1^{\text {st }}$ and $2^{\text {nd }}$ eye surgery $(p>0.05)$. The diastolic blood pressure value measured before the operation and

Table 3. Comparison of intergroup and intragroup VAS-Anxiety, STAI-S and STAI-T mean scores according to the first and second eye surgery

\begin{tabular}{|c|c|c|c|c|c|}
\hline \multirow{2}{*}{ Anxiety } & \multicolumn{2}{|c|}{ First eye surgery } & \multicolumn{2}{|c|}{ Second eye surgery } & \multirow{2}{*}{${ }^{1} p$-value } \\
\hline & $\overline{\mathbf{x}}$ & SD & $\overline{\mathbf{x}}$ & SD & \\
\hline \multicolumn{6}{|l|}{ VAS-anxiety } \\
\hline Before going to the operating room & 3.350 & 2.070 & 3.150 & 0.231 & $p=0.388$ \\
\hline Before surgery & 4.510 & 2.120 & 4.483 & 0.282 & $p=0.844$ \\
\hline During surgery & 3.780 & 1.960 & 4.150 & 0.283 & $p=0.211$ \\
\hline Immediately after surgery & 2.600 & 1.580 & 2.933 & 0.258 & $p=0.374$ \\
\hline After taken to the clinic & 2.010 & 1.290 & 2.317 & 0.216 & $p=0.425$ \\
\hline${ }^{2} p$-value & \multicolumn{2}{|c|}{$p=0.000$} & \multicolumn{3}{|c|}{$p=0.000$} \\
\hline \multicolumn{6}{|l|}{ STAI-State } \\
\hline Before going to the operating room & 37.40 & 5.53 & 35.85 & 5.47 & $p=0.003$ \\
\hline After taken to the clinic & 37.16 & 5.10 & 37.83 & 6.81 & $P=0.834$ \\
\hline${ }^{2} p$-value & \multicolumn{2}{|c|}{$p=0.777$} & \multicolumn{3}{|c|}{$p=0.007$} \\
\hline \multicolumn{6}{|l|}{ STAI-Trait } \\
\hline Before going to the operating room & 49.31 & 6.12 & 50.11 & 5.86 & $p=0.078$ \\
\hline
\end{tabular}




\begin{tabular}{|c|c|c|c|c|c|}
\hline \multirow{2}{*}{ Pain } & \multicolumn{2}{|c|}{ First eye surgery } & \multicolumn{2}{|c|}{ Second eye surgery } & \multirow{2}{*}{${ }^{1} p$-value } \\
\hline & $\overline{\mathbf{x}}$ & SD & $\overline{\mathbf{x}}$ & SD & \\
\hline During surgery & 2.86 & 1.39 & 3.35 & 2.07 & $p=0.580$ \\
\hline Immediately after surgery & 3.86 & 1.70 & 4.51 & 2.12 & $p=0.010$ \\
\hline After taken to the clinic & 3.55 & 1.66 & 3.78 & 1.96 & $p=0.265$ \\
\hline${ }^{2} p$-value & \multicolumn{2}{|c|}{$p=0.077$} & \multicolumn{3}{|c|}{$p=0.002$} \\
\hline
\end{tabular}

the pulse and respiratory rate measured during the operation in the $1^{\text {st }}$ eye surgery were higher than those measured in the $2^{\text {nd }}$ eye surgery $(p<0.05)$. In the within-group evaluation, the diastolic blood pressure value during the $1^{\text {st }}$ eye surgery was higher than all other measurements $(p<0.05)$ (Table 5$)$.

\section{Patients' Perception of Anxiety and Pain}

When patients were asked to compare the pain and anxiety levels they felt in $1^{\text {st }}$ and $2^{\text {nd }}$ eye surgery, $51.7 \%$ stated that they experienced more pain in the second eye surgery and $38.3 \%$ experienced an equal level of anxiety in both eye operations.

\section{Discussion}

High levels of anxiety in the surgical process can cause an increase in pain sensitivity and negatively affect physiological parameters such as blood pressure and heart rate (27). In this context, the study sought answers to the questions relating to the difference between pain and anxiety levels and physiological parameters of patients who underwent phacoemulsification procedure on both eyes at different times, and how these variables changed through the stages of measurement.

The first important finding of this study was that patients had higher state anxiety levels before the first eye surgery compared to the second eye surgery. This finding was similar to that of Nijkamp et al. (28). Researchers explained this finding saying that the cataract surgery was not performed by the same person and in the same way. It would be a mistake to make the same comment for the present study. In the present study, all patients were operated by the same surgical team and two eye surgeries of the same patients were compared. Therefore, the state anxiety levels of the patients were observed to be not affected only by the surgical team and the surgical procedure. Some studies report that the age and education level of the patients should be taken into consideration especially when informing patients regarding the surgery. Low education levels with advanced age may increase anxiety by decreasing the permanence and comprehensibility of the information provided (28). Considering that the patients participating in this study were at an advanced age and that the majority of them had a primary level of education, the results were not so surprising. Also, the patients were informed by the physician in the outpatient clinic in the hospital where the study was conducted. These results suggest that the preoperative patient training should be done by taking patient characteristics into account and by allocating sufficient time to patients. Besides, nurses should take an active role in the preoperative training process of cataract surgery.

The second important finding of this study was the high preoperative and perioperative anxiety perceptions of the patients in the second eye surgery and the high postoperative state-trait anxiety levels after they were taken to the clinic. Ramirez et al. (19) determined that the source of anxiety in the preoperative period was related to the surgery itself and the fear of losing eyesight and that the fear of the surgery continued in the postoperative period, causing anxiety. This finding is important in terms of showing that patients need psychological support for fear and anxiety management in second eye surgery. In a randomized controlled study on patients undergoing cataract surgery conducted by Haripriya et al. (29), the determination of the fact that patients who received counseling during the 


\begin{tabular}{|c|c|c|c|c|c|c|c|}
\hline \multirow{2}{*}{\multicolumn{3}{|c|}{$\begin{array}{l}\text { Table } 5 . \text { Compariso } \\
\text { saturation mean va } \\
\text { Measurement steps }\end{array}$}} & \multirow{3}{*}{\begin{tabular}{|l|} 
First ey \\
$\overline{\mathbf{x}}$ \\
123.00
\end{tabular}} & \multirow{3}{*}{\begin{tabular}{|l|} 
SD \\
14.53
\end{tabular}} & \multicolumn{2}{|c|}{ Second eye surgery } & \multirow{3}{*}{$\begin{array}{l}{ }^{1} p \text {-value } \\
p=0.66\end{array}$} \\
\hline & & & & & $\overline{\mathbf{x}}$ & \multirow{2}{*}{\begin{tabular}{|l|} 
SD \\
1.468
\end{tabular}} & \\
\hline \multirow{30}{*}{ 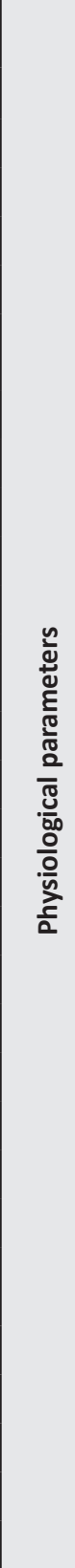 } & \multirow{6}{*}{ 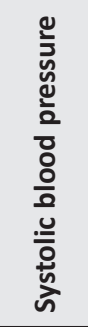 } & Before going to the operating room & & & 122.583 & & \\
\hline & & Before the surgery & 151.53 & 21.31 & 148.467 & 2.961 & $p=0.25$ \\
\hline & & During the surgery & 150.52 & 23.15 & 148.500 & 2.604 & $p=0.277$ \\
\hline & & Immediately after the surgery & 146.42 & 22.28 & 146.417 & 2.641 & $p=0.952$ \\
\hline & & After taken to the clinic & 125.58 & 11.72 & 126.417 & 1.513 & $p=0.529$ \\
\hline & & ${ }^{2} p$-value & \multicolumn{2}{|c|}{$p=0.992$} & \multicolumn{2}{|l|}{$p=0.215$} & \\
\hline & \multirow{6}{*}{ 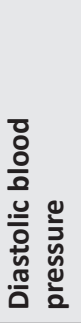 } & Before going to the operating room & 74.25 & 8.77 & 74.883 & 1.264 & $p=0.611$ \\
\hline & & Before the surgery & 81.53 & 12.60 & 80.983 & 1.322 & $p=0.038$ \\
\hline & & During the surgery & 85.73 & 12.87 & 83.150 & 1.293 & $p=0.064$ \\
\hline & & Immediately after the surgery & 81.95 & 12.09 & 83.000 & 1.228 & $p=0.668$ \\
\hline & & After taken to the clinic & 75.21 & 7.13 & 75.517 & 0.821 & $p=0.914$ \\
\hline & & ${ }^{2} p$-value & \multicolumn{2}{|c|}{$p=0.026$} & \multicolumn{2}{|l|}{$p=0.221$} & \\
\hline & \multirow{6}{*}{ 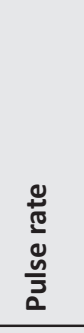 } & Before going to the operating room & 75.767 & 1.31 & 77.667 & 1.402 & $p=0.121$ \\
\hline & & Before the surgery & 78.317 & 1.60 & 78.300 & 1.731 & $p=0.074$ \\
\hline & & During the surgery & 77.333 & 1.74 & 76.550 & 1.591 & $p=0.000$ \\
\hline & & Immediately after the surgery & 76.450 & 1.52 & 76.233 & 1.428 & $p=0.966$ \\
\hline & & After taken to the clinic & 75.533 & 1.32 & 76.083 & 1.030 & $p=0.354$ \\
\hline & & ${ }^{2} p$-value & \multicolumn{2}{|c|}{$p=0.350$} & $p=0.101$ & & \\
\hline & \multirow{6}{*}{ 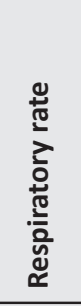 } & Before going to the operating room & 23.400 & 0.209 & 23.067 & 0.220 & $p=0.251$ \\
\hline & & Before the surgery & 23.933 & 0.346 & 23.533 & 0.313 & $p=0.330$ \\
\hline & & During the surgery & 24.000 & 0.389 & 23.600 & 0.414 & \\
\hline & & Immediately after the surgery & 23.733 & 0.295 & 23.000 & 0.275 & $p=0.094$ \\
\hline & & After taken to the clinic & 23.600 & 0.227 & 23.333 & 0.216 & $p=0.405$ \\
\hline & & ${ }^{2} p$-value & \multicolumn{2}{|c|}{$p=0.763$} & \multicolumn{2}{|l|}{$p=0.928$} & \\
\hline & \multirow{6}{*}{ 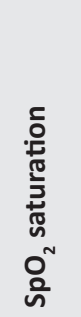 } & Before going to the operating room & 95.25 & 0.26 & 95.433 & 0.243 & $p=0.565$ \\
\hline & & Before the surgery & 95.16 & 0.34 & 95.283 & 0.317 & $p=0.779$ \\
\hline & & During the surgery & 95.65 & 0.29 & 95.717 & 0.264 & $p=0.592$ \\
\hline & & Immediately after the surgery & 95.91 & 0.27 & 95.933 & 0.211 & $p=0.850$ \\
\hline & & After taken to the clinic & 95.25 & 0.24 & 94.917 & 0.216 & $p=0.093$ \\
\hline & & ${ }^{2} p$-value & \multicolumn{2}{|c|}{$p=0.700$} & \multicolumn{2}{|l|}{$p=0.604$} & \\
\hline
\end{tabular}

surgical process experienced less fear than those who did not experience it showed the effect of counseling on psychological factors. However, during second eye surgery, subjective sensations such as photosensitivity, the sensation of swelling in the eyes, and pain were reported to increase (15). Therefore, the level of anxiety felt during the second eye surgery may increase with other subjective sensations. 
The third important finding of this study was that the pain score measured immediately after the end of the surgery was higher in the $2^{\text {nd }}$ eye surgery compared to the $1^{\text {st }}$ one. Regarding the within-group evaluation, the pain scores measured in the $2^{\text {nd }}$ eye surgery immediately after the operation were higher. Studies showed that many patients who underwent cataract surgery with topical anesthesia felt more pain during the second eye surgery compared to the first one (8,13-15). Zhu et al. (30), on the other hand, explained the increased pain level in the second eye by handling the issue on a physiological dimension. In their study, they reported that the concentration of MCP-1, pain-related inflammatory cytokines in the first eye, increased during the second eye surgery, causing higher levels of pain. It was also emphasized that adding an anti-inflammatory drug to the treatment plan to prevent macular edema in patients after the first eye surgery would be effective in reducing pain (31). In the present study, considering that an antiinflammatory drug was added to the treatment plan after the first eye surgery by the surgeon performing the operation, the necessary measures were thought to be taken to avoid a physiological effect on the pain during surgery. At the same time, the results show that the provision of information by nurses about the prescribed drugs in the discharge training content of patients undergoing cataract surgery is very valuable. In the study, although there was no pain during the second eye surgery, increased pain was observed immediately after the operation. In a study in which Porela-Tiihonen et al. (5) evaluated postoperative pain after cataract surgery, approximately one-third of the patients reported pain symptoms in the early postoperative period, and the majority of these patients $(79 \%)$ were determined to leave the hospital with pain symptoms. Especially in patients with high anxiety, pain sensitivity was reported to increase and the patients were found to tend to exaggerate pain (20). In this study, too, high postoperative state anxiety scores, as well as high postoperative pain scores, suggest that psychosocial factors other than physiological events play a role in explaining the source of pain. This finding also suggests that patients may have difficulties with home care after the first eye surgery (use of anti-inflammatory drugs, eye care, etc.) and that the increased pain level after the second eye surgery may be related to patients' concerns about postoperative care. Therefore, it should be remembered that there is a possibility that high anxiety and inadequate social support for eye care may lead to an increase in the level of pain. However, it should not be forgotten that pain may be a serious complication indicator. For this reason, the surgical team must well identify the pathologies represented by these different causes of pain (1). At this stage, physiological parameter data can be used to objectively evaluate the change in the severity of pain.

The fourth important finding of this study was that the diastolic blood pressure value measured before the operation and the pulse and respiration rates of patients measured during the surgery were higher in the $1^{\text {st }}$ eye surgery than those of the $2^{\text {nd }}$ eye surgery. In the within-group evaluation, the value of diastolic blood pressure during the $1^{\text {st }}$ eye surgery was higher than all other measurements. In the study of Jiang et al. (8) on cataract surgery patients, there was no change in physiological parameter measurements during both eye surgery operations. In the same study, when they examined the correlation between subjective measurements such as anxiety and pain and objective measurements such as physiological parameters, the blood pressure and pulse rate were found to vary according to the level of anxiety in the second preoperative period, and the number of diastolic blood pressure and pulse rate of the patients were determined to increase as pain severity increased. The researchers stated that monitoring the perioperative blood pressure and pulse rate values may help determine painful patients during surgery (8). In this study, considering the high anxiety and postoperative pain of the patients during the second eye surgery, physiological parameters are expected to increase as reported by studies in the literature. However, despite the high pain and anxiety, the pulse rate and diastolic blood pressure were observed to decrease in patients in the second eye surgery. Therefore, objective data suggest that patients' pain and anxiety levels may be lower than reported and these subjective measurements may vary according to the patient's perception. Indeed, while some researchers examining the possible causes of increased pain during the second eye surgery 
said anxiety was the underlying cause of pain in the second eye surgery (20), some studies suggested that this depended on the perception of the patient $(8,14,21)$. In this study, when the patients were asked to compare their perception of pain and anxiety they felt in two eye surgeries, the results were not much different from those reported in the surgical process. The patients stated that second eye surgery was a more painful experience, but that they experienced a similar level of anxiety in both eye surgeries. Because pain has many physical, emotional, perceptual, and psychosocial dimensions and there is the possibility that they may affect the patient with all these aspects in the surgical process, the results show that other factors affecting patients' perception of anxiety and pain should be evaluated comprehensively.

\section{Conclusion}

The state anxiety levels of the patients were higher in the first eye surgery compared to the second eye surgery. Although patients indicated high levels of anxiety during the second eye surgery, diastolic blood pressure, respiration and pulse values, which were among the physiological parameters, indicated more intensive anxiety findings in the first eye surgery. Patients had higher pain scores soon after the second eye surgery and higher state-anxiety scores after they were taken to the clinic. In conclusion, the results of subjective (pain and anxiety) and objective (blood pressure and heart rate) measurements in this study showed that the anxiety experienced in the first eye cataract surgery made the perceived anxiety and sensation of pain more sensitive in the second eye surgery.

This study was carried out in January 2020 in Nevsehir Haci Bektas, Veli University Health Sciences Faculty Institute of Nursing Department has been produced from the master thesis entitled "Pain and Anxiety During Cataract Surgery: A Comparison Between The First and Second Eye Surgeries".

\section{Ethics}

Ethics Committee Approval: This study was conducted with an approval from the Nevşehir $\mathrm{Hacl}$ Bektaş Veli University Ethics Committee (decision no: 2018/10, date: 10.09.2018).

Informed Consent: The written consent of the participants was obtained.

Peer-review: Externally peer-reviewed.

\section{Authorship Contributions}

Concept: G.K.Ç., C.A.A., F.I., Design: F.I.,, G.K.Ç., C.A.A., Supervision: F.I.,, G.K.Ç., C.A.A., Fundings: C.A.A., G.K.Ç., Materials: F.I.,, G.K.Ç., C.A.A., Data Collection or Processing: C.A.A., G.K.Ç., Analysis or Interpretation: F.I., G.K.C.., C.A.A., Literature Search: C.A.A., G.K.Ç., Writing: G.K.Ç., C.A.A., Critical Review: F.I., C.A.A., G.K.Ç.

Conflict of Interest: No conflict of interest was declared by the authors.

Financial Disclosure: The authors declared that this study received no financial support.

\section{References}

1. Assam JH, Bernhisel A, Lin A. Intraoperative and postoperative pain in cataract surgery. Surv Ophthalmol 2018; 63: 75-85.

2. Alam M, Saleem M. Sub conjunctival versus perıbulbar local anaesthesıa in cataract surgery. Gomal Journal of Medical Sciences 2011; 9: 128-30.

3. Akkaya S, Özkurt YB, Aksoy S, Kökçen HK. Differences in pain experience and cooperation between consecutive surgeries in patients undergoing phacoemulsification. Int Ophthalmol 2017; 37: 545-52.

4. Dadacı Z, Borazan M, Öncel Acır N. Pain Perception in Phacoemulsification with Topical Anesthesia and Evaluation of Factors Related with Pain. Turk J Ophthalmol 2016; 46: 151-5.

5. Porela-Tiihonen S, Kaarniranta K, Kokki M, Purhonen S, Kokki H. A prospective study on postoperative pain after cataract surgery. Clin Ophthalmol 2013; 7: 1429-35.

6. Rothschild PR, Grabar S, Le Dû B, Temstet C, Rostaqui O, Brézin AP. Patients' subjective assessment of the duration of cataract surgery: a case series. BMJ Open 2013; 3: e002497.

7. Yilmaz E, Birer Z, Baydur $H$. The effect of Therapeutic touch performed during cataract surgery on anxiety and patient satisfaction. Journal of Clinical and Experimental Investigations 2016; 7: 52-6.

8. Jiang L, Zhang K, He W, Zhu X, Zhou P, Lu Y. Perceived Pain during Cataract Surgery with Topical Anesthesia: A Comparison between First-Eye and Second-Eye Surgery. J Ophthalmol 2015; 2015: 383456.

9. Abacıoğlu S. Katarakt cerrahisi yapılacak hastalarda 1. ve 2. göz cerrahileri öncesi, hastaların endişe düzeylerinin araştrııması. Yayınlanmamış Yüksek Lisans Tezi (Unpublished master of medicine thesis). Afyon: Afyon Kocatepe Üniversitesi, Sağlık Bilimleri Enstitüsü, 2009.

10. Anuja BS, Devi ES, Sequira L, Rao L, Pai VH. Effectiveness of Intra operative hand holding on anxiety and physiological parameters among patients undergoing cataract surgery. Nitte University Journal of Health Science 2014; 4: 27-33.

11. Hari-Kovacs A, Lovas P, Facsko A, Crate ID. Is second eye phacoemulsification really more painful? Wien Klin Wochenschr 2012; 124: 516-9. 
12. Adatia FA, Munro M, Jivraj I, Ajani A, Braga-Mele R. Documenting the subjective patient experience of first versus second cataract surgery. J Cataract Refract Surg 2015; 41: 116-21.

13. Shi C, Yuan J, Zee B. Pain Perception of the First Eye versus the Second Eye during Phacoemulsification under Local Anesthesia for Patients Going through Cataract Surgery: A Systematic Review and Meta-Analysis. J Ophthalmol 2019; 2019: 4106893.

14. Ursea R, Feng MT, Zhou M, Lien V, Loeb R. Pain perception in sequential cataract surgery: comparison of first and second procedures. J Cataract Refract Surg 2011; 37: 1009-14.

15. Yu JG, Ye T, Huang Q, Feng YF, Wang J, Fu XA, et al. Comparison between Subjective Sensations during First and Second Phacoemulsification Eye Surgeries in Patients with Bilateral Cataract. J Ophthalmol 2016; 2016: 6521567.

16. Bardocci A, Ciucci F, Lofoco G, Perdicaro S, Lischetti A. Pain during second eye cataract surgery under topical anesthesia: an intraindividual study. Graefes Arch Clin Exp Ophthalmol 2011; 249: 1511-4.

17. Sharma NS, Ooi JL, Figueira EC, Rosenberg ML, Masselos K, Papalkar DP, et al. Patient perceptions of second eye clear corneal cataract surgery using assisted topical anaesthesia. Eye (Lond) 2008; 22: 547-50.

18. Liu $P$, Zhang $S$, Geng $Z$, Yuan $R$, Ye J. Factors affecting pain in patients undergoing bilateral cataract surgery. Int Ophthalmol 2020; 40: 297-303.

19. Ramirez DA, Brodie FL, Rose-Nussbaumer J, Ramanathan S. Anxiety in patients undergoing cataract surgery: a pre- and postoperative comparison. Clin Ophthalmol 2017; 11: 1979-86.

20. Demircan S, Ataş M, Altunel O, Gülhan A, Zararsız G. Anksiyetenin katarakt cerrahisi uygulanan hastalarda uyum ve intraoperatif ağrı üzerine etkisi. Glokom-Katarakt/Journal of GlaucomaCataract 2014; 10: 278-82.

21. Aslan L, Aslankurt M, Cekic O, Aksoy A, Yildiz H. The pain experience and cooperation of patients in consecutive cataract surgery. Eur J Ophthalmol 2013; 23: 339-43.

22. Spielberger CD, Gorsuch RL, Lushene R, Vagg PR, Jacobs GA. Manual for the State-Trait Anxiety Inventory. Palo Alto, CA: Consulting Psychologists Press, 1983.

23. Öner N, LeCompte WA. Durumluk-sürekli kaygı envanteri el kitabı. Boğaziçi Üniversitesi Yayınları, no:133; 1985.

24. Cline ME, Herman J, Shaw ER, Morton RD. Standardization of the visual analogue scale. Nurs Res 1992; 41: 378-80.

25. Eti-Aslan F. Ağrı Değerlendirme Yöntemleri. C.Ü. Hemşirelik Yüksekokulu Dergisi 2002; 6: 9-16.

26. Davis G. The Evolution of Cataract Surgery. Mo Med 2016; 113 : 58-62.

27. Kekecs Z, Jakubovits E, Varga K, Gombos K. Effects of patient education and therapeutic suggestions on cataract surgery patients: a randomized controlled clinical trial. Patient Educ Couns 2014; 94: 116-22.

28. Nijkamp MD, Kenens CA, Dijker AJ, Ruiter RA, Hiddema F, Nuijts $\mathrm{RM}$. Determinants of surgery related anxiety in cataract patients. Br J Ophthalmol 2004; 88: 1310-4.

29. Haripriya A, Tan CS, Venkatesh R, Aravind S, Dev A, Au Eong KG. Effect of preoperative counseling on fear from visual sensations during phacoemulsification under topical anesthesia. J Cataract Refract Surg 2011; 37: 814-8.

30. Zhu XJ, Wolff D, Zhang KK, He WW, Sun XH, Lu Y, et al. Molecular Inflammation in the Contralateral Eye After Cataract Surgery in the First Eye. Invest Ophthalmol Vis Sci 2015; 56: 5566-73.

31. Zhang Y, Du Y, Jiang Y, Zhu X, Lu Y. Effects of Pranoprofen on Aqueous Humor Monocyte Chemoattractant Protein-1 Level and Pain Relief During Second-Eye Cataract Surgery. Front Pharmacol 2018; 9: 783. 